\title{
Global Environmental Coordination: How to Overcome the Double Collective Action Problematic?
}

\author{
Jan-Erik Lane \\ University of Freiburg, Freiburg im Breisgau, Germany \\ Email: janeklane@googlemail.com
}

Received August 19 $9^{\text {th }}, 2012$; revised October $12^{\text {th }}, 2012$; accepted October $26^{\text {th }}, 2012$

\begin{abstract}
The need for stronger global coordination of environmental policies has become ever more obvious, but there are no formal arrangements in sight. The UN framework of UNEP is not delivering effective policies. Only global environmental coordination on the successful model of the World Band and the IMF can stem the rising emissions numbers and projections - quantitative voting reflecting the differences in size between the states of the world. However, the system of weighted voting typical of the WB and the IMF must be reformed in an egalitarian manner, when a global ecology organisation is set up, reducing their excessive voting power disparities. This paper suggests a simple but effective mechanism for reducing these voting power disparities, decreasing all member country votes by either the square root or the cube root expression.
\end{abstract}

Keywords: Ecological Capital; Global Environmental Coordination; Economic and Environmental Interdependencies; Tragedy of the Commons; Greenhouse Gases; Depletion of Environmental Resources; Global Environmental Agency; Weighted Voting; Coleman-Banzhaf Voting Power

\section{Introduction}

Planet Earth is running down its ecological capital. Whereas its economical capital—real or financial-tends to augment every year, resulting in sustained economic growth, the environmental assets of the world are shrinking, day by day and year in year out. All the available evidence point at the coming of a major ecological deficit the next decades, involving the decimation of endangered species, the overexploitation of oceans, seas and forests as well as the slow but steady poisoning of the atmosphere, leading to climate change. Why has it proved impossible to halt this slow but continuous erosion of global ecological capital?

To account for the dismal failure to protect the environmental assets of the world-the great animals, clean air, fresh water, tropical forests, graze lands, etc., I will turn to late sociologist James S. Coleman and his two ideas, developed from game theory (Coleman, 1986, 1998):

1) Non-economical capital: Coleman concentrated upon social capital, or trust, but I would argue that ecological capital is even more important for the future of mankind; there is an urgent need for collective action in order to protect global environmental assets from rapid depletion. This is the first collective action problem: the tragedy of the commons, or how to stem the over utilization of open access resources (Coleman, 1998).

2) Capacity to decide in groups: Coleman employed the Penrose-Banzhaf framework to show that groups that employ unanimity become essentially powerless, only producing transaction costs. I will show that this second collective action problem of stalemate among veto players in the global group of all states is making global environmental coordination a so-called "Polish Diet"- the liberum veto (Coleman, 1971).

Thus, at the core of the problematic of protecting ecological capital is two classical collective action problems: first free riding upon open access resources, reducing ecological capital day by day, and second the failure of the governments of the states of the world to decide upon global environmental coordination and set up an agency to enforce a global policy.

\section{The UN Framework}

The UN has engaged in global environmental policy-making during the last two decades, resulting in global meetings with resolutions concerning important principles, e.g., sustainability. The United National Environment Program (UNEP) is the framework for the United Nations involvement environmental issues at the global and regional level, comprising a very broad mandate is to coordinate the governments of the countries in the world towards environmental policy consensus by means of global environment review, bringing emerging issues to the attention of governments and the international community for action. Yet, the enforcement problematic has not at all been addressed. Environmental coordination lacks a global organisation that can follow up on what happens with all the declarations and intentions, monitor real developments in various continents and engage in practical activities that promote environmental sustainability.

The Stern Review (2007) is probably correct in calling the $\mathrm{CO}_{2}$ emissions the largest market failure ever for mankind. The governments of the countries of the world must be interested in global environmental coordination, as the risks involved are enormous. Constant meetings of heads of states and premiers have thus far not resulted in any credible policy, halting the increase in greenhouse gases. The need for global environmental coordination relates not only the climate change problematic but covers all kinds of issues in the environmental predicament of Mother Earth, like for instance safeguarding bio- 
diversity and protecting endangered species, i.e. counter-acting the constantly ongoing depletion of ecological capital (Balmford, 2002; Tol, 2002a, 2002b; Nordhaus, 2007; Weitzman, 2007).

\section{Economic Capital against Ecological Capital}

As the process of globalisation rolls on year in and year out, the states of the world become dependent upon each other. The inter-dependencies between countries-economically, environmentally and culturally — call for common policy-making, i.e. coordination of decision-making. The often heard call for global governance is only credible if it can deliver a theory about effective decision-making. However, the global meetings of governments result in little or nothing except sometimes nonbinding recommendations when it comes to protecting ecological capital.

\section{Global Economic Interconnectedness}

This Marxian contradiction between ONE global environment on the one hand and some 200 states in need of policy coordination in response to the challenges of globalisation is extremely difficult to resolve. On the one hand, the representatives of each and every state will want to have a SAY in global decision-making - the unanimity principle. On the other hand, respecting the will of each of the 200 governments would lead to staggering transaction costs in negotiations. Is there a way out of the veto-transaction cost problematic that can save global reunions from coordination failures like e.g. the Copenhagen Summit on Climate Change?

The interconnectedness in the global economy has become so large that any major shock hurts almost all economies in the world (Bhagwati, 2004). The amount of interaction in the global economy is typically measured with the IMPEX indica- tor, which divides imports plus exports with the GDP. Diagram 1 shows the constantly growing IMPEX scores for the global economy, which follow closely the expansive trend for global output and world trade.

Global trade and foreign direct investments remain the engine that power global economic expansion. Constantly increasing economic interactions between countries not only cement ONE global economy, but also push the GDP of most countries steadily higher. Growth in aggregate output means that it is easier to fight poverty, but it comes with a most important consequence, namely the reduction in global ecological capital, as for instance the steady increase in $\mathrm{CO}_{2}$ emissions, poisoning the atmosphere and leading to global warming.

\section{Environmental Interdependency: $\mathrm{CO}_{2}$ Emissions as a Result of GDP Growth}

The emission of greenhouse gases, as measured by Energy Information Administration, has been on sharp rise for twenty years. And they are predicted to keep rising considerably in the stylised scenario for the next twenty years. How could all the meetings of the governments of the world change this trend? The principal difficulty stems from an almost unavoidable green-growth trade-off. The $\mathrm{CO}_{2}$ equivalent emissions are a strict function of economic development, i.e. rising GDP. Economic expansion must have cheap energy, and thus far only the burning of the fossil fuels has provided this vital input to the global market economy. Figure 1 shows the close association between GDP and emissions.

As the emerging economies in Asia, Africa and South America are heading for 5 - 10 percent GDP growth yearly, the total emissions must increase, perhaps sharply. One could argue that future GDP expansion will come by energy saving innovations

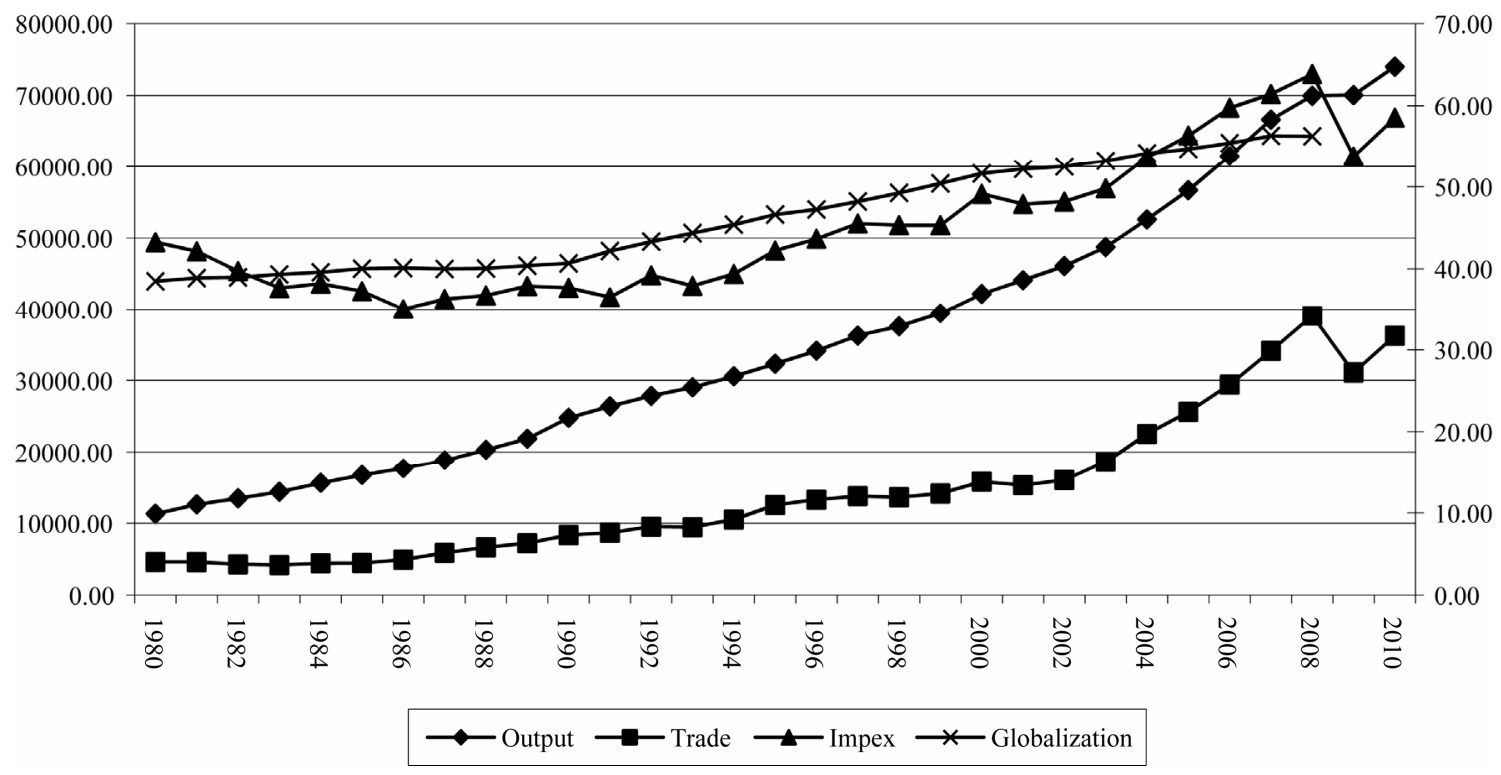

Diagram 1.

Interconnectedness: IMPEX scores, trade and global GDP. Source: Output = Gross domestic product based on purchasing-powerparity (PPP) valuation of country GDP; Current international dollar; Billions (left axis); Trade = Imports and exports of goods and services; Current dollars; Billions (left axis); Impex = Trade/Gross domestic product, current prices; Current dollars; Billions (right axis); Globalization = Means for KOF index (Dreher, 2006) for 174 constant countries (right axis); Sources: IMF (2010) World Economic Outlook Database; available via: http://www.imf.org/external/pubs/ft/weo/2010/02/weodata/index.aspx. Dreher, Axel (2006): Does Globalization Affect Growth? Evidence from a new Index of Globalization, Applied Economics 38, 10: 1091-1110; data available via: http://globalization.kof.ethz.ch/ 


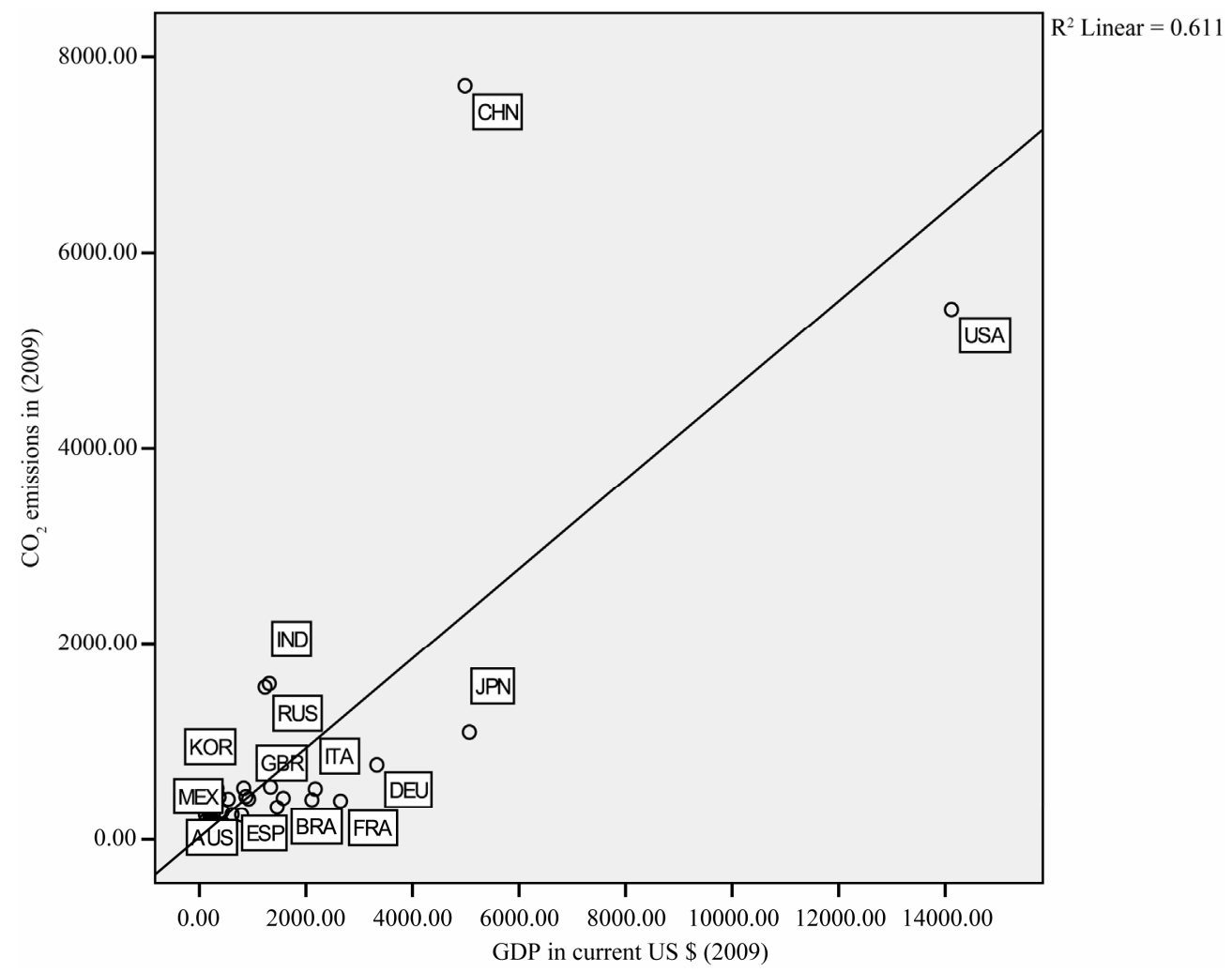

Figure 1.

Country $\mathrm{CO}_{2}$ emissions against country GDP 2009. Note: $\mathrm{CO}_{2}$ emissions + Population: EIA (2011) International Energy Statistics; data available from: http://www.eia.gov/cfapps/ipdbproject/IEDIndex3.cfm; GDP data: World Bank (2011) World Development Indicators; data available from http://databank.worldbank.org/ddp/home.do.

that make possible economic development without burning more fossil fuels. However, Figure 2 shows that the emissions per GDP are not very high in the most affluent countries, meaning that there is little space for savings in emissions per capita.

There are two fundamental trends in the growth-emissions problematic. On the one hand, a higher level of GDP requires more energy that leads to more emissions. On the other hand, a more advanced economy employs less of emissions per GDP unit. It is the first trend that is the strongest in the world today, resulting in an inexorable rise in the global emission of greenhouse gases, believed to the man made cause of global warming syndrome.

If the governments of the countries of the world are sincere about the ambition to stem the progressions of $\mathrm{CO}_{2}$ emissions, then they must create a strong international organisation that monitors the future trend in emissions as well as decide about counter measures, like a $\mathrm{CO}_{2}$ tax or a carbon emissions trading scheme. This agency should be given the tasks of improving the overall environmental predicament of the Earth, including safeguarding bio-diversity, protecting the open seas, maintaining fresh water resources, guaranteeing the survival of endangered species-i.e. reducing the overall ecological deficit of Planet Earth by increasing ecological capital.

\section{Global Economic Coordination}

It is an axiom in theories of capitalism and the market economy that they do not constitute self-regulating systems of human interaction. Thus, Max Weber (1978) called attention to the relevance of firm institutionalisation in order to make modern capitalism (the market economy) different from "capitalisme sauvage". As an economic historian of the institutionalist bend, he devoted much effort to pinning down how the rules of the market economy had evolved from other forms of capitalism: rural, feudal and state.

Stiglitz $(2003,2006,2007)$ raises the need to clarify and amplify institutions as modern capitalism has been transformed into one global market economy, thus resulting in a need for a bigger role for global economic management by international organizations in order to enhance fair trade and empower Third World countries. Stiglitz calls for radical changes in the market economy itself as a response to the need for achieving justice or global fairness by means of global economic management (Stiglitz, 2007, 2010; Stiglitz \& Charlton, 2007; Serra \& Stiglitz, 2008; Chang, 2001). At the same time, he recognizes, like Bhagwati (2004) that only the institutionalised global market economy can efficiently create wealth and improve on poverty in the Third World (Stiglitz, Ocampo, Spiegel, French-Davis, \& Nayyar, 2006). What global economic coordination first and foremost needs is a reform of the voting regimes of $\mathrm{WB}$ and IMF, which could be employed also for an effective regime of ecological coordination.

\section{Relevance of Weighted Voting}

Two types of voting regimes can be distinguished: quantitative regimes and qualitative regimes in economic coordination. 


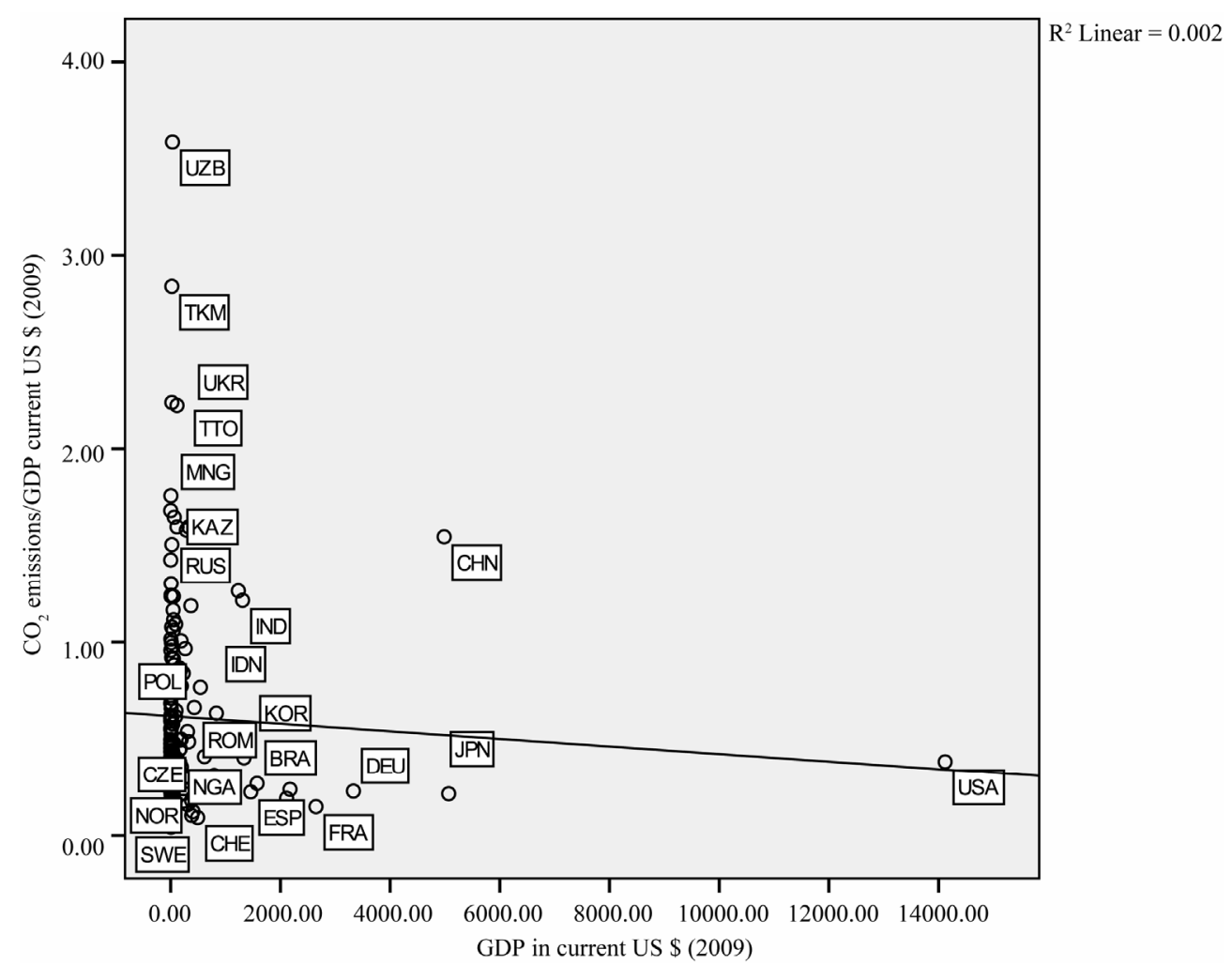

Figure 2.

$\mathrm{CO}_{2}$ emissions per GDP against total economic output (GDP). Note: $\mathrm{CO}_{2}$ emissions + Population: EIA (2011) International Energy Statistics; data available from: http://www.eia.gov/cfapps/ipdbproject/IEDIndex3.cfm; GDP data: World Bank (2011) World Development Indicators; data available from http://databank.worldbank.org/ddp/ home.do.

The first is employed by the World Bank and the IMF, while the second is used by the World Trade Organisation (WTO). The World Bank and the IMF with quantitative voting have sharply differentiated voting rights, reflecting the contribution of capital to these organizations. Thus, a few member states have a huge number of votes, whereas other large economies have few votes. This creates a fundamental imbalance in global governance, with the World Bank and the IMF being dominated by the Western powers plus Japan (triad). This imbalance may have been a necessity after the Second World War when China, India, Nigeria and Brazil were extremely poor. But today a redistribution of voting rights is feasible and desirable.

The WTO with qualitative voting is unbalanced in terms of the distribution of votes, but for another reason than the one just suggested. Here, all member countries have the same number of votes: that is, one vote for the US and for Djibouti e.g.a quite unrealistic situation given the immense differences in trade among the roughly 160 member countries in the WTO. Since the WTO employs narrow qualified majority and one state-one vote, the small member states receive a voting power that is completely unrelated to their relative size in global trade. This makes the WTO unwieldy, running up transaction costs (Jones, 2009; Steger, 2009), blocking further advances in the global trade regime.

In the World Bank and the IMF, the opposite problem exists. Thus, heavy quantitative voting has resulted in the virtual dominance of the so-called "triad" comprising the US, the EU and Japan: see Table 1: “actual distribution”.
As appears from Table 1, the distribution of votes in both of these organizations have been highly skewed to the advantage of the triad. (Western powers plus Japan). Since these two organizations employ qualified majorities (85\%), the dominance of the three vote-heavy countries becomes complete. The uneven vote distribution has no doubt reflected the situation in the past, but it is no longer in tune with economic realities. The emerging economies are increasingly calling for a balanced composition of these global management bodies. Whereas the World Bank and the IMF should consider reducing the inequalities in vote allocation while giving more votes to the emerging economies, the WTO should reflect on the possibility of introducing some form of quantitative voting.

\section{Reform Formulas of Weighted Voting Regimes}

The most simple and practical of alternative schemes for reducing the immense differences in the allocation of votes consists of starting from the status quo, but taking, for example, the square root or perhaps even better the cube root of the present allocation of votes, as modelled in Table 1: "square root or cube root distribution”. Such a simple institutional reform would preserve policy effectiveness while substantially reducing unjust power inequalities that stem from extreme differences in votes. China could at the same time be invited to take a bigger amount of voting rights by means of capital injection, thus also bolstering the capital basis of these IGO:s. The suggested formula, using Coleman-Banzhaf voting power numbers, 
Table 1.

Allocation of votes and Coleman-Banzhaf voting power in the WB and the IMF 1989-2010.

\begin{tabular}{|c|c|c|c|c|c|c|c|c|c|c|}
\hline \multirow[b]{2}{*}{$\begin{array}{c}\text { Country/Group of } \\
\text { Members }\end{array}$} & \multirow{2}{*}{$\begin{array}{l}\text { Group/ } \\
\text { Country } \\
\text { Quotas }\end{array}$} & \multicolumn{3}{|c|}{ Actual Distribution } & \multicolumn{3}{|c|}{ Square Root Distribution } & \multicolumn{3}{|c|}{ Cube Root Distribution } \\
\hline & & $\begin{array}{c}\text { Share of } \\
\text { Votes }\end{array}$ & $\begin{array}{c}\text { Banzhaf } \\
\text { Voting } \\
\text { Power }\end{array}$ & $\begin{array}{l}\text { Power to } \\
\text { Block }\end{array}$ & $\begin{array}{l}\text { Share of } \\
\text { Votes }\end{array}$ & $\begin{array}{c}\text { Banzhaf } \\
\text { Voting } \\
\text { Power }\end{array}$ & $\begin{array}{l}\text { Power to } \\
\text { Block }\end{array}$ & $\begin{array}{l}\text { Share of } \\
\text { Votes }\end{array}$ & $\begin{array}{c}\text { Banzhaf } \\
\text { Voting } \\
\text { Power }\end{array}$ & $\begin{array}{c}\text { Power to } \\
\text { Block }\end{array}$ \\
\hline United States & 371,743 & 16.79 & 0.064 & 1.000 & 8.68 & 0.057 & 0.983 & 6.84 & 0.051 & 0.895 \\
\hline Japan & 133,378 & 6.02 & 0.057 & 0.895 & 5.20 & 0.050 & 0.854 & 4.86 & 0.047 & 0.824 \\
\hline Germany & 130,332 & 5.89 & 0.057 & 0.888 & 5.14 & 0.050 & 0.853 & 4.83 & 0.047 & 0.824 \\
\hline France & 107,635 & 4.86 & 0.051 & 0.807 & 4.67 & 0.047 & 0.812 & 4.53 & 0.046 & 0.807 \\
\hline United Kingdom & 107,635 & 4.86 & 0.051 & 0.807 & 4.67 & 0.047 & 0.812 & 4.53 & 0.046 & 0.807 \\
\hline Belgium/Austria & 113,969 & 5.15 & 0.053 & 0.833 & 4.80 & 0.048 & 0.826 & 4.61 & 0.046 & 0.815 \\
\hline Netherlands/Ukraine & 105,937 & 4.78 & 0.051 & 0.801 & 4.63 & 0.047 & 0.809 & 4.50 & 0.045 & 0.804 \\
\hline Spain/Mexico & 98,659 & 4.45 & 0.049 & 0.768 & 4.47 & 0.046 & 0.789 & 4.40 & 0.045 & 0.796 \\
\hline Italy/Greece & 90,968 & 4.11 & 0.046 & 0.725 & 4.29 & 0.045 & 0.766 & 4.28 & 0.044 & 0.782 \\
\hline China & 81,151 & 3.66 & 0.043 & 0.668 & 4.05 & 0.043 & 0.730 & 4.12 & 0.043 & 0.762 \\
\hline Canada/Ireland & 80,636 & 3.64 & 0.042 & 0.664 & 4.04 & 0.042 & 0.727 & 4.11 & 0.043 & 0.760 \\
\hline Indonesia/Singapore & 78,068 & 3.53 & 0.041 & 0.650 & 3.98 & 0.042 & 0.717 & 4.07 & 0.043 & 0.754 \\
\hline Korea/Australia & 76,311 & 3.45 & 0.041 & 0.640 & 3.93 & 0.041 & 0.709 & 4.04 & 0.042 & 0.749 \\
\hline Sweden/Norway & 76,276 & 3.44 & 0.041 & 0.640 & 3.93 & 0.041 & 0.709 & 4.04 & 0.042 & 0.749 \\
\hline Egypt/Lebanon & 70,852 & 3.20 & 0.038 & 0.603 & 3.79 & 0.040 & 0.688 & 3.94 & 0.041 & 0.730 \\
\hline Saudi Arabia & 70,105 & 3.17 & 0.038 & 0.599 & 3.77 & 0.040 & 0.684 & 3.92 & 0.041 & 0.726 \\
\hline Sierra Leone/Lesotho & 66,763 & 3.01 & 0.036 & 0.571 & 3.68 & 0.039 & 0.667 & 3.86 & 0.040 & 0.716 \\
\hline Switzerland/(none) & 61,827 & 2.79 & 0.034 & 0.537 & 3.54 & 0.038 & 0.644 & 3.76 & 0.039 & 0.697 \\
\hline Russian Federation & 59,704 & 2.70 & 0.033 & 0.522 & 3.48 & 0.037 & 0.636 & 3.72 & 0.039 & 0.689 \\
\hline Iran, IR/Morocco & 53,662 & 2.42 & 0.030 & 0.476 & 3.30 & 0.035 & 0.596 & 3.59 & 0.037 & 0.658 \\
\hline Brazil/Colombia & 53,634 & 2.42 & 0.030 & 0.476 & 3.30 & 0.035 & 0.596 & 3.59 & 0.037 & 0.658 \\
\hline India/Sri Lanka & 52,112 & 2.35 & 0.030 & 0.465 & 3.25 & 0.034 & 0.589 & 3.56 & 0.037 & 0.651 \\
\hline Argentina/Uruguay & 43,395 & 1.96 & 0.025 & 0.394 & 2.96 & 0.031 & 0.524 & 3.34 & 0.034 & 0.595 \\
\hline Rwanda/Togo & 29,855 & 1.35 & 0.018 & 0.275 & 2.46 & 0.023 & 0.400 & 2.95 & 0.025 & 0.439 \\
\hline Decisiveness & & & 0.00066 & & & 0.00026 & & & 0.00018 & \\
\hline
\end{tabular}

Note: On calculating the Coleman-Banzhaf voting power index numbers-see Coleman, 1971 and especially Felsenthal and Machover, 1998: Source: http://www.imf.org/ external/np/sec/memdir/members.html. Recently very minor changes in the share of votes have been done (Bryant, 2008; Leech \& Leech, 2012).

can be formulated in even more egalitarian formulas.

\section{New Agency for Environmental Coordination}

I suggest the creation of a new global environmental agency. If composed according to the model of WB or IMF (although with much more egalitarian voting scheme), it could do a lot to counteract the overall environmental degradation globally. It could be financed by the carbon taxes or from the emission rights trading with the surplus going to the funding of the global environmental operations, like saving endangered species etc.

Global coordination is, generally speaking, extremely difficult to achieve, due to the combined veto-transaction cost problematic. Only two agencies of global coordination work effectively today, namely the World Bank and the IMF. Why?
Because they have overcome unanimity and reduced transaction costs by employing the institution of weighted voting.

A global ecological agency should be empowered with enough resources and staff to embark upon programs that effectively enhance environmental sustainability, reversing the trend towards depletion of global ecological capital. There is so much to be done to protect endangered species, monitor tropical forests, improving upon energy producing facilities by filters etc., and safeguarding fresh water as well as surveying the condition of the oceans, seas and lakes as well as water tables (Constanza, 1997; Sala et al., 2000; Chapin, 2002).

\section{Conclusion}

Global environmental coordination must overcome two fun- 
damental types of collective action difficulties: on the one hand the depletion of ecological capital (tragedy of the commons) and on the other hand the unanimity-stalemate typical of state coordination. The UN framework of UNEP with all its meetings and consultations lack enforcement capacity and resources to take action. The voting regime of the WB and the IMF shows that global coordination can be done effectively. Weighted voting is a proper institution for global coordination, but the allocation of voting rights must not be too skewed. By reforming the scheme in the WB and the IMF, simply taking the square root or the cube root of the present allocation, a viable format for global coordination can be constructed, allowing for certain but not excessive differences in state voting power as well as overcoming the veto-transaction cost problematic. Global environmental coordination can only work if these is a strong agency devoted to these tasks permanently, operating on the basis of quantitative voting.

The inexorable degradation of the global environment involves yearly losses of ecological capital. The international and regional environmental coordination has not been effective in halting this dismal process for planet Earth (Rosendal, 1995; Meyer et al., 1997; Raustiala, 1997), despite the increase in the recognition of environmental values (Regan, 1983; Taylor, 1986; Attfield, 1999; Singer, 2002). Only a powerful global environmental agency constructed on the model of global economic coordination and entrusted with proper resurces-economic and legal ones-can stem the global tragedy of the Commons: the final elimination of endangered species, the pollution of water and sea assets, the poisoning of the atmosphere and the cutting down of rain forests and spreading of deserts.

\section{REFERENCES}

Attfield, R. (1997). The ethics of the global environment. Edinburgh: Edinburgh University Press.

Balmford, A. (2002). Economic reasons for conserving wild nature. Science, 297, 950-953. doi:10.1126/science.1073947

Bhagwati, J. (2004). Defense of globalization. New York: Oxford University Press.

Bryant, R. C. (2008). Reform of quota and voting shares in the international monetary fund: "Nothing" is temporarily preferable to an inadequate "Something". Washington DC: Brookings Institution.

Chang, H.-J. (2001). Joseph Stiglitz and the world bank: The rebel within. London: Anthem Press.

Chapin, F. S., Erika, S. Z., Valerie, T. E., Rosamond, L. N., Peter, M. V., Heather, L. R., David, U. H., Sandra, L., Osvaldo, E. S., Sarah, E. H., Michelle, C. M., \& Sandra, D. (2002). Consequences of changing biodiversity. Nature, 405, 234-242. doi:10.1038/35012241

Coleman, J. S. (1971). Control of collectivities and the power of a collectivity to act. In Lieberman (Ed.), Social choice (pp. 277-287). New York: Gorden and Breach. Reprinted in Coleman, J. S. (1986). Individual interests and collective actions. Cambridge University Press, Cambridge, England.

Coleman, J. S. (1998). Foundations of social theory. Cambridge, MA: Harvard U.P.

Costanza, R., Ralph d'Arge, Rudolf de Groot, Stephen, F., Monica, G., Bruce, H., Karin, L., Shahid, N., Robert, V. O., Jose, P., Robert, G. R., Paul, S., \& Marjan, van den B. (1997). The value of the world's ecosystem services and natural capital. Nature, 387, 253-260. doi:10.1038/387253a0

EIA (2010). Energy information administration.

http://www.eia.doe.gov/

Felsenthal, D., \& Machover, M. (1998). The measurement of voting power. Cheltenham: Edward Elgar.

Global footprint network: Global footprint.

(http://www.footprintnetwork.org/en/index.php/GFN/page/footprint_ basics overview/

Jones, K. (2009). The doha blues: Institutional crisis and reform in the WTO. London: Zed Books.

Leech, D., \& Leech, R. (2012). A new analysis of a priori voting power in the IMF: Recent quota reforms give little cause for celebration. Warwick Economic Research Papers.

Meyer, J. W., David, J. F., Ann, H., Evan, S., \& Nancy, B. T. (1997). The structuring of a world environmental regime, 1870-1990. International Organization, 4, 623-651. doi:10.1162/002081897550474

Nordhaus, W. D. (2007). A review of the stern review on the economics of climate change. Journal of Economic Literature, 45, 686-702. doi:10.1257/jel.45.3.686

Nunes, P., \& van den Bergh, C. J. M. (2001). Economic valuation of biodiversity: Sense or nonsense?” Ecological Economics, 2, 203-222. doi:10.1016/S0921-8009(01)00233-6

Raustiala, K. (1997). States, NGOs and international environmental institutions. International Studies Quarterly, 4, 719-740. doi:10.1111/1468-2478.00064

Regan, T. (1983). The case for animal rights. Berkeley, CA: University of California Press.

Rosendal, G. K. (1995). The convention on biological diversity: A viable instrument for conservation and sustainable use?” In H. Bergenson, G. Parmann, \& O. B. Thommessen (Eds.), Green globe year book of international co-operation. Oxford: Oxford University Press.

Sala, O. E., Chapin III, F. S., Armesto, J. J., Eric, B., Janine, B., Rodolfo, D., Elisabeth, H.-S., Laura, F. H., Robert, B. J., Ann, K., Rik, L., David, M. L., Harold, A. M., Martín, O., Poff, N. L., Martin, T. S., Brian, H. W., Marilyn, W., \& Diana, H. W. (2000). Global biodiversity scenarios for the year 2100. Science, 287, 1770-1774. doi:10.1126/science.287.5459.1770

Serra, N., \& Stiglitz, J. E. (2008). The Washington consensus reconsidered: Towards a new global governance. Oxford: Oxford U.P.

Singer, P. (2002). One world: The ethics of globalization. New Haven, CT: Yale University Press.

Steger, D. S. (2009). Redesigning the World Trade Organization for the 21st century. Waterloo, ON: The Centre for International Governance Innovation (CIGI) and Wilfrid Laurier University Press.

Stern, N. (2007). The economics of climate change (the stern review). Cambridge, MA: Cambridge U.P.

Stiglitz, J. E. (2003). Globalization and its discontents. New York: W. W. Norton.

Stiglitz, J., Ocampo, J. A., Spiegel, S., Ffrench-Davis, R., \& Nayyar, D. (2006). Stability with growth: Macroeconomics, liberalization and development. Oxford: Oxford University Press.

Stiglitz, J. E. (2007). Making globalisation work. The next steps to global justice. New York: Penguin.

Stiglitz, J. E. (2010). Freefall: Free markets and the sinking of the global economy. London and New York: Allen Lane.

Stiglitz, J. E., \& Charlton, A. (2007). Fair trade for all. Oxford: Oxford U.P.

Taylor, P. W. (1986). Respect for nature. Princeton, NJ: Princeton University Press.

Tol, R. (2002a). Estimates of damage costs of climate change. Part I: Benchmark estimates. Environmental and Resource Economics, 21, 47-73. doi:10.1023/A:1014500930521

Tol, R. (2002b). Estimates of damage costs of climate change. Part II: Dynamic estimates. Environmental and Resource Economics, 21, 135-160. doi:10.1023/A:1014539414591

Weber, M. (1978). Economy and society. Berkeley, CA: University of California Press.

Weitzman, M. L. (2007). A review of the stern review on the economics of climate change. Journal of Economic Literature, 45, 703-724. doi:10.1257/jel.45.3.703 